\title{
The Effect of Audit Committee Financial Expertise And Relative Status On Earnings Management: Case of Indonesia
}

\author{
Delfita Siagian and Sylvia Veronica Siregar \\ Faculty of Economics and Business Universitas Indonesia \\ E-mail adress: sylvia.veronica@ ui.ac.id
}

\begin{abstract}
The aim of this research is to examine the effect of audit committee financial expertise (measured by audit committee experience in accounting, supervision, and financial)and audit committee status (relative to management) on earnings management. Our samples consist of 384 observations in Indonesia Stock Exchange for the year 20122014. The result of this research shows that audit commite financial expertise has no significant effect on earnings management. However, we find evidence that audit committee financial expertise haspositive effect on income decreasing accruals. This finding indicates that audit committee may perceived that conservatism is one of the mechanism to restrict management opportunistic behavior. We do not find significant evidence of the joint effect of audit committee status and audit committeee expertise on earnings management.
\end{abstract}

Keywords: audit committe, discretionary accruals, earnings management, financial expertise, relative status

\section{BACKGROUND}

There are many cases of financial reporting manipulation around the world, including Enron and WorldCom in USA, Parmalat in Italy, Satyam in India, as well as Informa in Indonesia. These earnings manipulation has caused stakeholders to suffer huge financial loss. This financial reporting manipulation has raised concerns over the effectiveness of corporate governance. Empirical evidence shows that effective corporate governance helps to reduce agency cost, as management optimized corporate resources for the best interest of shareholders (Lin and Hwang, 2010). Widespread economic crisis across Asia, including Indonesia, in 1997 gave rise to awareness of the importanceof good corporate governance implementation within Indonesian companies. Implementation of good corporate governance in Indonesia was intensified, owing to improvement made by regulators for existing regulations and guidelines, such as regulations by OJK/Bapepam LK, BEI regulations, Bank Indonesia's regulations, decrees of Minister of State-Owned Enterprises, and Indonesian Code of Corporate Governance. This was also evidenced by a large number of improved regulations for enhanced quality of corporate governance applied by Indonesian companies.Financial Services Authority of Indonesia or Otoritas Jasa Keuangan (OJK/formerly Bapepam LK) and PT. Indonesia Stock Exchange or Bursa Efek Indonesia (BEI) concurrently brought forth a number of regulations related to 
corporate governance. One of the corporate governance mechanisms related to financial reporting monitoring is audit committee.

On September 24, 2004, OJK/Bapepam LK Chairman published Bapepam-LK Regulation No. IX.I.5 on the Establishment and Implementation Guidelines of Audit Committees which obliged public companies to have audit committees and establishment guidelines of such committees in place. BEI then issued Decree of PT BEI Board of Directors No. KEP-00001/BEI/01-2-14 on Amendment of Regulation No. I-A on the Listing of Stocks and Equity-Type Securities other than Stocks Issued by Listed Companies emphasizing the obligation of public companies to have audit committees in place. Both the BEI Decree and Bapepam LK Regulations stipulated that an audit committee was to be composed of a minimum of one independent commissionerand 2 (two) other members out of the issuer or the said public company. The regulations also set the number of independent commissionersat a minimum percentage of $30 \%$ serve as independent commissioners.

The major role of audit committees in assisting the board of commissioners in overseeing financial reporting process and the overall process has become more significant in order to establish good corporate governance (Siregar \& Utama, 2006). Bapepam-LK Regulation No. IX.I.5 regulating audit committee independence, tenure, and meetings is also one of the efforts to maintain good corporate governance within Indonesian listed companies.It has become increasingly important for audit committees to take on the responsibility for financial reporting quality (Financial Reporting Council, 2010). However, in the wake of Enron Corporation's downfall andAndersen's dismissal, the burning question is whether audit committee monitoring can ensure financial reporting quality and earnings managementreduction.

Audit committee financial expertise is expected to reduce corporate fraud (Abbott et al., 2004). Another study supports this finding, stating that a negative relation exist between audit committee financial expertise and corporate fraud in 2000-2001 (Agrawal and Chadha,2005). Severalstudies also suggest that the more independent committee members with financial expertise, the more effective audit committee will be. Siagian \& Tresnaningsih (2011) find a negative relation between audit committee independence and earnings management. According to Dhaliwal et al. (2010), financial and accounting expertise are able to improve financial reporting quality.

Several studies find contrary evidence. For example, Ghosh et al. (2010) find that audit composition does not affect earnings management.Siregar \& Utama (2006) conducted research in Indonesia and find that the audit committee existence did not have a significant effect on earnings management. Nugroho and Eko (2011) also supported that finding. This insignificant results might have been because Indonesian public companies only comply with the minimal requirement as set forth in regulations. This purpose of complying with the regulationscause the audit committee not function effectively.

According to Badolato et al., (2014), financial expertise and audit committee independence will not be effective unless audit committees have some sort of power or a higher status than the management. Thus, the effect of audit committee financial expertise on earnings management will also expected to increase due to the relative high status of audit committee relative to management. A status of audit committees with competence and leadership skills will have a stronger influence on tighter control over financial 
information (D'Aveni, 1990; Pollock et al., 2010). Why audit committee higher status than the management may reduce earnings management? Audit committee needs both ability and authority to get respect from management in order for audit committee to exercise its financial reporting monitoring function effectively. Management will have more positive view on audit committee as audit committee is becoming more competent and authoritative, hence will reduce management incentive to engage in earnings management. Audit committee with high status will also more induce to exercise active monitoring, including questioning suspiscious managerial reporting choices (Badolato et al., 2014).

Therefore, it is interesting to examine the effect of financial expertise on earnings management as well as the joint effect of financial expertise and audit committee relative status on earnings management. We do not include accounting regularities as in Badolato et al. (2014) to measure earnings manipulation. This is because there is limited data available to measure errors and irregularities in Indonesia.

There are many literature examining earnings management issue as well as audit committee financial expertise in other countries, especially in USA. Badolato et al. (2014) find that both audit committee financial expertise and relative status are associated with lower earnings management. Indonesia is an interesting setting, considering there are several literature documenting weak corporate governance in Indonesia. For example, CLSA analyses and ratesAsia-Pacific marketson their performance in corporate governance. Latest report from CLSA (CG Report Watch 2016) put Indonesia on the bottom ranking of 12 markets rated by CLSA. Therefore, it is interesting to examine whether audit committee financial expertise and relative status will have similar effect on constraining earnings management, as the finding in the developed market.

\section{THEORETICAL REVIEW}

Agency issues often arise in the midst of conflicting goals between shareholders (principals) and managers (agents). Separation of ownership and management results in information asymmetry which then resulted in requirement for the firm to provide financial reports to shareholders. If a financial report does not reflect the actual corporate performance, stakeholders are susceptible to decision-making pitfalls. As such, it is necessary to monitor a corporate financial reporting process in order to improve financial reporting quality. One of the primary keys is the function of an audit committee which serves as both a supervisor and controller in assisting the board of commissioners with respect to financial reporting supervision.

An audit committee is an important and indispensable component of a corporate financial reporting supervision. According to Bapepam-LK Regulation No. IX.I.5, audit committees appointed to assist the board of commissioners in supervising management activities in a corporate financial reporting process. In order to be able to assess accounting policy selection the management are implementing, audit committee members have to possess analytical skills in accounting and finance such that they can come up with absolutely transparent reports. To effectively monitor a corporate financial reporting process, each memberof the committees is required to have a solid understanding of finance in order to be able to analyze financial reports (Dhaliwal et al., 2010). Financial expertise in audit committee membersis also needed to identify and ask questions that 
challenge management and external audit to improve higher financial reporting quality (Bedard \& Gendron, 2010). This will increase corporate reporting transparency and decrease agency issues related to information flows.

Chang and Sun (2009) find a significant negative relation between financial expertisein audit committees and earnings management. Lo et al. (2010) also find consistent result in Shanghai Stock Exchange. Lin and Hwang (2010) find qualitatively the same results. In this study, audit committee expertise is divided into accounting expertise, financial expertise, and supervisory expertise. We measure earnings management using discretionary accruals using Kasznik (1999). Based on this argument, the hypotheses are as follows:

H1a : Audit committee accounting expertise has a negative association with discretionary accruals.

H1b : Audit committee financial expertise has a negative association withdiscretionary accruals.

H1c : Audit committee supervisory expertise has a negative association withdiscretionary accruals.

Audit Committee Status. A status is an ability of an individual to influence results based on personal expertise, quality, and characteristics (Erkens and Bonner, 2013). An individual with a higher status hasa higher ability and authoritative leadership. A status is a crucial part of audit committees which affects their ability to acquire more information and to maintain the active monitoring of corporate financial reporting.D'aveni (1990) measured statuses based on education, board of directors membership, and work experience in other companies. The result shows that status has a negative relation with a company's bankruptcy due to creditors' trust in the company's status. A status of audit committees higher than that of the management may reinforce the influence of audit committee financial expertise on deterring management actions to conduct earnings management which violates regulations as well as standards and which is why this research will focus on the relative status of audit committees compared to the status of top management.Based on this particular argument, the hypotheses are as follows:

H2a : Higher status of audit committees than that of the management strengthens the negative association between the effectof audit committee accounting expertise on discretional accruals.

H2b : Higher status of audit committees than that of the management strengthens the negative relation associationthe effect of audit committee financial expertise on discretional accruals.

H2c : Higher status of audit committees than that of the management strengthens the negative relation associationthe effect of audit committee supervisory expertise on discretional accruals.

\section{METHOD}

This research is aimedat examining whether audit committee expertise as well as status differentials of audit committees and management has association with earnings management. We use following research model to test our hypotheses: 


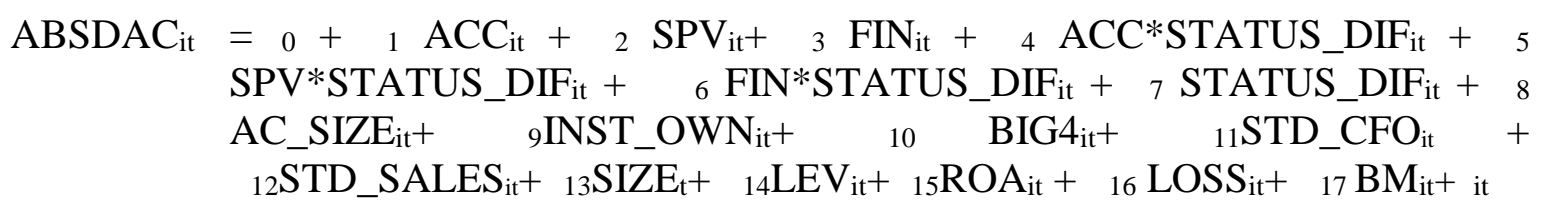

We use Random Effect Model (REM) panel regression to run above research model.

Dependent Variable. Dependent variablesused in this research is earnings management measured using discretionary accruals based on Kasznik (1999).Siregar and Utama (2008) shows that Kasznik (1999) is the best estimation model.

$\mathrm{TAC}_{\mathrm{it}}=\beta_{0}+\beta_{1} *\left(1 / \mathrm{ASSETS}_{\mathrm{it}-1}\right)+\beta_{2} *\left(\Delta \mathrm{REV}_{\mathrm{it}}-\Delta \mathrm{AR}_{\mathrm{it}}\right)+\beta_{3} * \mathrm{PPE}_{\mathrm{it}}+\beta_{4} * \Delta \mathrm{CFO}_{\mathrm{it}}+\varepsilon$

$\mathrm{TAC}_{\mathrm{it}}=$ total accrual (net income less cash flows from operating activities); ASSETS $_{\mathrm{it}-1}=$ lagged total assets; $\Delta \mathrm{REV}_{\mathrm{it}}=$ changes in revenue; $\Delta \mathrm{AR}_{\mathrm{it}}=$ changes in receivables; $\mathrm{PPE}_{\mathrm{it}}=$ gross property, plant, and equipment; $\Delta \mathrm{CFO}_{\mathrm{it}}=$ changes in cash flows from operation. All variables are deflated by lagged total assets. We use cross sectional version of Kasznik (1999) and use the residuals from above model to measure discretionary accruals.

Independent Variables. Audit Committee Financial Expertise. Financial expertise is measured by a percentage of audit committee expertise out of 3 types of finance-related expertise, namely accounting, supervisory and financial expertise, based on the percentage of the number of audit committee members with those types of expertise. Independent variables for accounting and financial expertise refer to education background and work experience in accounting. Work experience specifications in this research refer to Badolato et al., (2014) as follows:

a) Accounting expertise is identified as a skill set in audit committee work experience as Chief Financial Officer (CFO), controllers, treasurers, account managers, certified public accountants, accountants, and accounting lecturers/professors.

b) Financial expertise is identified as a skill set in audit committee work experience asaccount managers, banking work experience, analyst, investment and fund managers.

c) Supervisory expertise is identified as a skill set in audit committee work experience as members of a company's board of directors or Chief Executive Officer (CEO).

Relative Status. This research examines status of audit committee members and that ofmanagement (CEO and CFO). Audit committee status is measured based on the previous researches by taking into account the following factors: multiple directorship of audit committees in public companies, educational background i.e. being graduates of reputable universities (Pollock et al., 2010) and levels of education. In order to measure the variable of being graduates from reputable universities, this research uses data collected from QS World University Rankings in 2015-2016. This research will test status differentials between audit committees and the management, namely CEO and CFO because both have the authority in financial reporting process. To measure the status of both audit committees and management, the following measurement is used:

1. Audit committee members serve as commissioners and audit committees in another company, this is a dummy variable. PUBLIC_BOARDS_AC equals one if the mean 
number of audit committees holding a commissioner position in a public company is greater than the median value of all audit committee members, and zerootherwise.

2. Audit committee members are graduates of reputable universities, this is a dummny variable. ELITE_EDUCATION_AC equals one if the mean number of reputable university educational background of audit committee members is greater than the median value of all audit committee members, and zero otherwise. To measure the variable of reputable university educational background, this research uses data collected from a webpage (in a website) of QS World University Rankings in 20152016(attachment 2).

3. Levels of education of audit committee members, to indicate their competence. DEGREE_EDUCATION_AC measurement with a dummy variable, which equals one if the mean number of master and doctoral graduates of audit committee members is greater than the median value of all audit committee members, and zero otherwise.

4. STATUS_AC is an indicator which equals one if the sum of PUBLIC_BOARDS_AC, ELITE EDUCATION_AC, and DEGREE_EDUCATION_AC of audit committees is three, and zerootherwise.

An example of STATUS_AC calculation is as follows. For example, PT AAA Tbk has 3 audit committee members with 2 of them being graduates from reputable universities (ELITE_EDUCATION_AC). That means ELITE EDUCATION_AC of PT AAA Tbk is $0.6(2 / 3)$. The same calculation can be performed on all sampled companies and the median value of all these samples can then be calculated. For instance, the median value of all samples is 0.5 . Since the mean number of reputable university graduates in AAA equals $0.6(2 / 3)$, the mean number of university graduates in the AAA audit committees is greater than the median value of all companies, which results in 1 (one).

To calculate management status (CEO and CFO) and status differentials of audit committees compared to the management, this research goes through the same basic steps by measuring audit committee status. STATUS_DIFERRENTIAL, the status of audit committees and managmeent, a rating of 1 if audit committee status is higher than management status.

Control Variables. We include several control variables in our model. Audit committee size (AC_SIZE) can reduce earnings management (Garcia et al., 2012; Badolato et al., 2014). This is due to the wide range of skills of audit committee members in exercising oversight on management. We predict negative association of audit committee size with earnings management. High institutional ownership in the company also increase the effective oversight of the management. Institutional ownership has the expertise and a strong monitoring incentive for direct monitoring and can influence the company's decision. Hadani et al. (2011) find that large institutional ownership in the company is able to prevent earnings management. We expect negative association of institutional ownership and earnings management.

Auditors with high quality tends to improve the quality of financial reporting and also transparency. Siregar\&utama (2006) argues that the Big-4 auditors have higher ability to restrict earnings management compared with non Big-4 auditors. We measure audit quality (AUD) using a dummy variable of 1 if company is audited by Big 4 nad 0 if otherwise. 
According to Dechow and Dichev (2002), firm risk also induces earnings management. We measure firm risk using the volatility of sales (STD_SALES) and volatility of cash flows (STD_CFO). More volatile of this items also provide incentive for management to engage in earnings management to reduce the volatility.

Companies with larger size (SIZE) more attention from various parties, including financial analysts and government than small enterprises. Therefore, large size companies will tend to avoid earnings management. Meiniand Siregar(2014) find that company size has a significant negative effect on earnings management. Firm size is measured using market capitalization at the end of the year. Companies with debt covenants tend to perform earnings management in order to avoid a violation of the agreement. Siregar\&utama (2006) argues that firms with high leverage have a high likelihood of earnings management. Leverage (LEV) is measured from the company's total debt to total assets of the company.

Companies that have high profitability will likely improve the quality of financial reporting. Gao and Kling (2012) state companies with high profitability level will tend to be better in disclosing the information. This study predicts a negative relationship between profitability (ROA) with earnings management. Kothari et al. (2005) suggest including ROA in earnings management research to control for firm's growth that may affect the results. In addition to ROA, we also include additional variable relate to profitability. Badolato et al. (2014) include loss as one of control variables affecting earnings management. One of the goals of earning management is to avoid losses. LOSS is predicted to have a negative association with discretionary accruals and measured by a dummy variable ( 1 if for companies suffered losses and 0 if otherwise).

Book to Market (BM) measure the level of growth. The greater the value of BM indicates high growth and predicted to have a positive association with earnings management for the sake of the growth expectations, management can make profit management. Book to market value derived from the book value of equity divided by the market value of equity

The Results of Statistical Tests. Based on sample selection criterion in Table 1, we have 384 observations from 2012 through 2014. We start our research in year 2012 due to Bapepam-LK Regulation No. X.K.6 was revised in 2012 and has more detailed requirement regarding company obligation to disclose background information on board members as well as audit committee members.

Table 1. Sample Selection

\begin{tabular}{lc}
\hline Criteria & Firm-years \\
\hline Listed firms at IDX during 2012-2014 & 1.477 \\
Financial industry & $(239)$ \\
Unavailable annual reports & $(639)$ \\
Incomplete data & $(215)$ \\
Total firm years & 384 \\
\hline
\end{tabular}

Data usedfor this research are secondary data collected from several sources, namelyData Stream and Eikon as well as corporate annual reports available on the official website of Indonesia Stock Exchange. 
The descriptive statistics of this research is presented in Table 2. Absolute discretionary accruals (ABSDAC) have the mean of 0.14673 . This mean is relatively large indicating that our observations in average has indications of engaging in earnings management in quite large amount. On average, audit committee accounting expertise (ACC) shows that companies have an average of $38.09 \%$ of audit committees with accounting expertise. If the average audit committee size is 3 persons (the required minimum number), then for each company, accordingly, has one audit committee member with accounting expertise. This is in compliance with OJK regulations. The descriptive statistics indicates that supervisory expertise in companies is an approximate average of $32.95 \%$ and only $8.36 \%$ for financial expertise.

Table 2. Descriptive Statistics

\begin{tabular}{lcrrrrr}
\hline \multicolumn{1}{c}{ Variable } & $\mathrm{N}$ & \multicolumn{1}{c}{ Mean } & $\begin{array}{c}\text { Standar } \\
\text { Deviasi }\end{array}$ & Minimum & Median & Maximum \\
\hline ABSDAC & 384 & 0.14572 & 0.2472 & 0.000291 & 0.0601711 & 1.6972 \\
ACC & 384 & 0.38086 & 0.29309 & 0 & 0.3333 & 1 \\
SPV & 384 & 0.32947 & 0.29568 & 0 & 0.3333 & 1 \\
FIN & 384 & 0.08364 & 0.17969 & 0 & 0 & 1 \\
AC_SIZE & 384 & 3.09945 & 0.44277 & 1.493951 & 3 & 4.7456 \\
INST & 384 & 0.04379 & 0.05690 & 0 & 0.0096 & 0.2285 \\
STD_CFO & 384 & 0.06086 & 0.05369 & 0.0007744 & 0.0480278 & 0.3039 \\
STD_SALES & 384 & 0.2058 & 0.1376 & 0.0024 & 0.0719 & 1.7266 \\
MVE (in million & 384 & $14,400,000$ & $38,700,000$ & 26,460 & $2,398,097$ & $308,000,000$ \\
Rp) & & & & & 0.237411 & 1.0367 \\
LEV & 384 & 0.26027 & 0.21616 & 0.2367 \\
ROA & 384 & 0.05532 & 0.09617 & -0.375432 & 0.0463656 & 0.4171 \\
BM & 384 & 0.82051 & 1.12390 & -3.43921 & 0.5788202 & 5.04232 \\
DUMMY & & $\mathbf{0}$ & $\mathbf{1}$ & & & \\
STATUS_DIF & & $49.74 \%$ & $50.26 \%$ & & & \\
BIG4 & & $51.30 \%$ & $48.70 \%$ & & & \\
LOSS & $85.94 \%$ & $14.06 \%$ & & & \\
\hline
\end{tabular}

ABSDAC: absolute discretionary accruals; ACC: percentageof audit committee members with accounting expertise; SPV: percentageof audit committee members with supervision expertise; FIN: percentageof audit committee members with financial expertise; AC_SIZE: the number of the audit committee members; INST: institutional ownership; STD_CFO: the volatility of cash flow divided by total assets; STD_SALES: volatility of sales divided by total assets; MVE: market capitalization; LEV: total debt divided by total assets; ROA: net profit after tax divided by total assets; BM: book-to-market; STATUS_DIF: Difference of the status of the audit committee with the status of the CEO and CFO; BIG4: 1 if company audited by Big 4 and 0 I=if otherwise; LOSS: 1 if company is experiencing losses and0 if otherwise

From the status differentials between audit committees and management showsquite high management status. There are $49.73 \%$ with management status higher than audit committee status. It shows that in many companies audit committee has relatively lower status than management, which may hinder the audit committee effectiveness.

The average number of audit committee members is 3 (in accordance with minimum requirements as set forth in OJK regulations). Number of companies employing Big 4 is 
quite balamced with non Big 4. LOSS suggest that companies suffering a financial loss make up only a small portion of $14.06 \%$.

Regression results isshown in Table 3. We can see from the regression results that audit committee members with accounting, supervisory, and financial expertise have a positive insignificant effect, thus all $\mathrm{H} 1$ hypotheses are not supported.These result do not support Xie et al. (2003) and Dhaliwal et al. (2010) who found that accounting experience has a negative effect on earnings management. However, these results support the findings in Yusof (2010) and Rahman et al. (2006) which find that the audit committee's financial and accounting expertise does not have any significant effect on earnings management.

Table 3. Regression Results

\begin{tabular}{|c|c|c|c|}
\hline \multicolumn{4}{|c|}{ 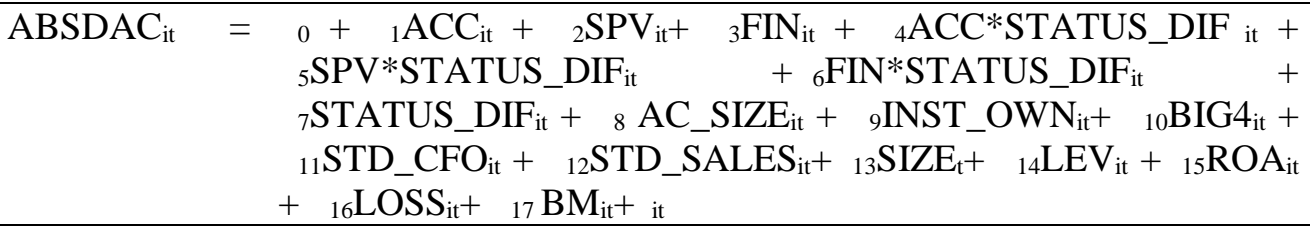 } \\
\hline Variables & Expected Sign & Coefficient & p-value \\
\hline $\mathrm{ACC}$ & $\mathrm{H} 1 \mathrm{a}-$ & 0.0849 & 0.139 \\
\hline SPV & H1b- & 0.0906 & 0.110 \\
\hline FIN & H1c- & 0.0853 & 0.200 \\
\hline STATUS_DIF & - & -0.0495 & $0.014 * *$ \\
\hline ACC*STATUS_DIF & $\mathrm{H} 2 \mathrm{a}-$ & 0.0074 & 0.470 \\
\hline SPV*STATUS_DIF & $\mathrm{H} 2 \mathrm{~b}-$ & -0.0145 & 0.439 \\
\hline FIN*STATUS_DIF & $\mathrm{H} 2 \mathrm{c}-$ & -0.0526 & 0.360 \\
\hline ACSIZE & - & 0.0391 & 0.113 \\
\hline INST_OWN & - & 0.4687 & $0.050 *$ \\
\hline STDEV_CFO & + & 0.6064 & $0.008 *$ \\
\hline STDEV_SALES & + & 0.1942 & $0.002 *$ \\
\hline BIG4 & - & 0.0319 & 0.155 \\
\hline LEV & - & -0.0097 & 0.452 \\
\hline ROAC & - & -0.0625 & 0.370 \\
\hline MVE & - & -0.0445 & 0.165 \\
\hline BM & + & -0.0047 & 0.367 \\
\hline LOSS & - & 0.0311 & 0.234 \\
\hline CONS & & 0.0821 & 0.010 \\
\hline \multicolumn{4}{|l|}{$\mathrm{F}-$ Test $=0.0084$} \\
\hline $\mathrm{R}$-Squared $=0.1314$ & & & \\
\hline
\end{tabular}

ABSDAC: absolute discretionary accruals; ACC: percentageof audit committee members with accounting expertise; SPV: percentageof audit committee members with supervision expertise; FIN: percentageof audit committee members with financial expertise; AC_SIZE: the number of the audit committee members; INST: institutional ownership; STD_CFO: the volatility of cash flow divided by total assets; STD_SALES: volatility of sales divided by total assets; MVE: market capitalization; LEV: total debt divided by total assets; ROA: net profit after tax 
divided by total assets; BM: book-to-market; STATUS_DIF: Difference of the status of the audit committee with the status of the CEO and CFO; BIG4: 1 if company audited by Big 4 and 0 I=if otherwise; LOSS: 1 if company is experiencing losses and 0 if otherwise

$* *$ Significant at $\alpha=5 \%$; Significant at $\alpha=1 \%$

Audit committees with expertise in accounting and finance are expected to reduce opportunistic earnings management. However, the results of our study do not find supporting evidence. This may be due to the appointment of audit committee that has expertise in accounting and finance is only to comply with prevailing regulation. This result is supported by the results of descriptive statistics in table 2 which show that audit committee members who have accounting expertise are still relatively small with an average of $38.08 \%$ and financial expertise with an average of $0.08 \%$. Bapepam's(now OJK) Regulation also has not explained in detail what characteristics can be stated as accounting/financial expertise. These results also show that audit committees in companies in Indonesia are still not efficient in carrying out their functions so that the financial expertise on the audit committee does not have a significant influence on reducing earnings management.

In addition, Sharma\&Kuang (2014) find that financial expertise of audit committee members has negative association with likelihood of aggressive earnings management, however this only applies when the financial expertise is held by independent directors. Maybe our insignificant result is due to the financial expertise is held by audit committee members other than independent commissioners.

To test hypotheses 2 , we interact the relative status of audit committee with the audit committee expertise. Audit committee higher status in comparison to management status will supposedly increase the negative association of audit committee accounting expertise on earnings management.ACC*STATUS variables has a positive but insignificant. Therefore, hypothesis $2 \mathrm{a}$ is not accepted. This finding is inconsistent with Badolato et al. (2014) which find that audit committee status higher than that of the management caused the management to have a tendency to avoid earnings management because the audit committees tend to have more authority in supervising financial reporting process. It is possible that education background may be not sufficient to be used as a basis to measure accounting expertise. If the audit committee member with accounting education background do not regularly updated its knowledge with latest development in accounting standards, thus he/she can not effectively monitor financial reporting quality.

The interaction variables between audit committee supervisory expertise and their status differentials (SPV*STATUS) also hasan insignificant effect (H2b is not supported). As such, there is no evidence that audit committee status differentials and management status reinforced the effect of audit committee supervisory and financial expertise on reducing the amount of earnings management. This is also inconsistent with Badolato et al. (2014). Supervisory experience is expected to escalate the capability of monitoring of financial reporting process and deter the management from engaging in earnings management. However, this supervisory expertise may have significant effect if the supervisory expertise is spesifically related to financial reporting supervisory. In our study, we have not identified suc specific supervisory expertise.Cohen et al. (2013) argue that accounting expertise is not sufficient in restricting earnings management. They posit that 
audit committee industry knowledge is very important because accounting guidance, estimates, and oversight of the external auditor are highly associatedwith company's operations within a particular industry. They find that audit committee members who have bothaccounting and industry expertise can improve the effectiveness of the audit committee in monitoring the financial reporting process.

The same finding also for interaction variables of audit committee financial expertise and status differentials (FIN*STATUS). This shows no evidence of the status being able to strengthens the negative effect of audit committee financial expertise on earnings management.As a result, hypothesis is rejected. The argument of this insignificant result is maybe because financial expertise may relate more with valuation issues, capital structure, or the company's cash flow not specifically related to earnings management. Thus, financial expertise does not necessarily mean that audit committee members have knowledge of financial reporting processes and accounting standards or audit experience that can help analyze the company's financial statements to assit them in detecting earnings management.

Bruynseels\&Cardinaels (2013) find that firms with audit committees that have "friendship" ties to the CEO have higher earnings management. Hence, it is possible, eventhough audit committee members have accounting, supervisory, and financial expertise, they may not function effectively if they have social ties with management.In addition, there is many companies with a lower audit committee status compared to toplevel management status (about 49.74\%), which may also explain why we cannot find significant evidence of audit committee status on earnings management.

Audit committee size has insignificant effect on discretionary accruals. The fact that in average companies have only 3 audit committee members, a size which perfectly complies with financial services authority regulations, may indicate that company may just want to comply with the regulation. Institutional ownership in contrary shows a positive effect on earnings management. This may indicate that there is not enough monitoring of institutional ownership in a firm which maybe due to relatively small institutional ownership of $4.49 \%$.

Both cash flow volatility and sales volatility have a positive and significant effect, consistent with Dechow and Dichev (2002).Company size has insignificant effect on earnings management. This is inconsistent with Siregar and Utama (2006)and Xie et al. (2003). This might be because both large and small businesses in Indonesia are still committing earnings management. Large companies are still have incentive to commit earnings management with the aim of avoiding earnings reduction.

In addition, there has no evidence that auditor quality has any effect on earnings management. This result supports Siregar and Utama (2006) as well as Christiani (2014).This might be due to all auditors provide the same audit quality due to they all already follow the audit standards. Another possibility is audit firm size do not necessarily represent audit quality (Siregar and Utama, 2008).

Leverage also do not have an insignificant effect on earnings management. The reason is that indebted companies in Indonesia do not have strict debt covenants so they do not commit earnings management to avoid violating debt covenants. It may also possible that debt-to-asset ratio do not able to capture the probability of violating debt covenant. 
Additional Tests. We conduct several additional test to examine whether our main results are robust. First, we include only one expertise and the interaction with relative audit status. The inclusion of all variables in the main test has the issue of high multicollinearity.Regression test results (untabulated) of each variable in audit committee financial expertise with interaction variable has similar results with main analysis. Audit committee financial expertise does not affect earnings management. The same is true of the role of higher audit committee status compared to management status, as there is no evidence that such a role can strengthens the effect of accounting expertise on earnings management.

Second, we also examine separately income increasing and income decreasing accruals (Table 4). Audit committee may have different concern over income increasing accruals and income decreasing accruals. Habbash et al. (2013) suggest that it is importantto distinguish between audit committee effectiveness on constraining upward and downward earnings management.We find that audit committee financial expertise in accounting and supervision have a positive significant effect on income decreasing discretionary accrualsbut do not have a significant effect on abnormal accruals increasing earnings. This suggests that audit committee accounting and supervisory expertise may tend to uphold conservative accounting principles because this conservatism are considered important to restrict management opportunistic behavior. The joint effect of audit committee status differentials and audit committee financial expertise again do not have any significant effect on earnings managements, consistent with the previous main results. The relative status does have direct effect in constraining income increasing discretionary accruals, consistent with main results.

The third additional tests combined variables of financial expertise consisting of accounting, financial and supervisory expertiseinto one variable, AC_EXP, which can affect earnings management. Regression results (untabulated) indicated consistent results suggesting that audit committee accounting and/or financial expertise do not affect earnings management. These results also indicated that there is no significant joint effect of status and audit committee expertise.

Table 4. Regression Results - Income Increasingvs Income Decreasing Sub Samples

\begin{tabular}{lcllll}
\hline \multirow{2}{*}{ Variabele } & \multirow{2}{*}{$\begin{array}{c}\text { Expected } \\
\text { Sign }\end{array}$} & \multicolumn{2}{c}{$\begin{array}{c}\text { Income Increasing } \\
\text { Discretionary Accruals }\end{array}$} & \multicolumn{2}{c}{$\begin{array}{c}\text { Income Decreasing } \\
\text { Discretionary Accruals }\end{array}$} \\
\cline { 3 - 6 } & & Coefficient & p-value & Coefficient & p-value \\
ACC & - & -0.1437 & 0.1665 & 0.1282 & $0.0315^{* *}$ \\
SPV & - & -0.1145 & 0.2155 & 0.1197 & $0.0365^{* *}$ \\
FIN & - & 0.2159 & 0.1165 & 0.0414 & 0.328 \\
STATUS_DIF & - & -0.0645 & $0.05^{* *}$ & -0.0283 & 0.12 \\
ACC*STATUS_DIF & - & 0.1971 & 0.138 & -0.0284 & 0.385 \\
SPV*STATUS_DIF & - & 0.1981 & 0.139 & -0.0131 & 0.4465 \\
FIN*STATUS_DIF & - & -0.2319 & 0.196 & 0.1009 & 0.2445 \\
ACSIZE & - & 0.0664 & $0.0915^{* * *}$ & -0.0191 & 0.2685 \\
INST_OWN & - & 0.9815 & $0.0155^{* *}$ & 0.2280 & 0.1805 \\
STDEV_CFO & + & 0.3304 & 0.2165 & 0.6462 & $0.0045^{* *}$ \\
STDEV_SALES & + & 0.4991 & $0.0000^{*}$ & 0.0405 & 0.2415 \\
\hline
\end{tabular}


Siagian and Veronica: The Effect of Audit Committee Financial Expertise...

\begin{tabular}{llllll}
\hline BIG4 & - & 0.0453 & 0.176 & -0.0211 & 0.225 \\
LEVERAGE & - & 0.0408 & 0.373 & 0.0296 & 0.3305 \\
ROA & - & -0.0710 & 0.4185 & -0.0196 & 0.455 \\
MVE & - & -0.1135 & $0.059^{* * *}$ & 0.0072 & 0.4265 \\
BM & + & 0.0031 & 0.4475 & -0.0100 & 0.1735 \\
LOSS & - & -0.0666 & 0.2045 & 0.1111 & $0.0025^{* *}$ \\
CONS & & 0.0782 & 0.0895 & 0.0697 & 0.0095 \\
Observations & & \multicolumn{2}{c}{196} & & 188 \\
F-test & & & 0.0037 & & 0.0012 \\
R-squared & & 0.2115 & & 0.2278 \\
\hline
\end{tabular}

ABSDAC: absolute discretionary accruals; ACC: percentage of audit committee members with accounting expertise; SPV: percentage of audit committee members with supervision expertise; FIN: percentage of audit committee members with financial expertise; AC_SIZE: the number of the audit committee members; INST: institutional ownership; STD_CFO: the volatility of cash flow divided by total assets; STD_SALES: volatility of sales divided by total assets; MVE: market capitalization; LEV: total debt divided by total assets; ROA: net profit after tax divided by total assets; BM: book-to-market; STATUS_DIF: Difference of the status of the audit committee with the status of the CEO and CFO; BIG4: 1 if company audited by Big 4 and $0 \mathrm{I}=$ if otherwise; LOSS: 1 if company is experiencing losses and 0 if otherwise **Significant at $\alpha=5 \%$; Significant at $\alpha=1 \%$

\section{CONCLUSION}

Audit committees with accounting and financial expertise are expected to be able to reduce earnings management. But, the result of this research do not find supporting evidence. It indicates that audit committee financial expertise in accounting, supervision, and finance do not affect earnings management. This is probably because establishment of audit committees in Indonesia is for the purpose of compliance with the regulations. In addition, the average audit committees with accounting, financial and supervisory expertise in our observations are still relatively small. In the additional test, we find that audit committee members with accounting and supervisory expertise have a positive effect on income decreasing discretionary accruals. This indicates that audit committees with accounting and supervisory expertise may tend to think that accounting conservatism can restrict management opportunistic behavior.

Higher audit committee status compared to top-level management status has no jont effect with audit committee expertise on earnings management. This might be because there ismanycompanies with a lower audit committee status compared to top-level management status, which accounts for $49.74 \%$.Our study has several limitations which provide avenue for further studies. We determine reputable universities based only on QS World University Ranking 2015-2016. Only select public universities and none of the private universities in Indonesia included in the lists in Indonesia.There are other audit committee characteristics that are not considered in this study, such as frequency of meeting. EventhoughKasznik (1999) is considered the best model based on Siregar and Utama (2008), there is no gurantee that the model is able accurately separate acruals into discretionary and non-discretionary components. Audit committee serves to assist board of 
commissioners in discharging the board responsibility in supervising board of directors. Future studies may also examine the joint effect of the role of board of commissioners' relative status and audit committee relative status on earnings management. Future studies may also examine the effect of audit committee status on other type of earnings management, namely real earnings management. Sun et al. (2014) examine the effect of independent audit committee on real earnings management. However, they have not examined the effect of audit committee status on real earnings management. We also have not examined the interaction between audit committee and external audit as in Alves (2013). Future studies mau examine these issues further.

\section{REFERENCES}

Abbott, L., Parker,S., andPeters, G. (2004). "Audit committee characteristics and restatements. Auditing: A Journal of Practice and Theory, 23, 69-87.

Agrawal, A., and Chadha, S. (2005). "Corporate governance and accounting scandals". Journal of Law \& Economics, 48 (2), 371-406.

Alves, S. (2013). "The impact of audit committee existence and external audit on earnings management: Evidence from Portugal". Journal of Financial Reporting \& Accounting, 11(2), 143-165.

Badolato, P. G., Donelson, D. and Ege, M. (2014). Audit committee financial expertise and earnings management: The role of status. Journal of Accounting and Economics. 58 (2), 208-230.

Bedard, J., andGendron,Y. (2010). Strengthening the financial reporting system: can audit committees deliver? International Journal of Auditing, 14, 174-210.

Bruynseels, L., \& Cardinaels, E. (2013). The audit committee: Management watchdog or personal friend of the CEO?, The Accounting Review, 89(1), 113-145.

Chang, J. and Sun, H. (2009). 'Crossed-listed foreign firms' earnings informativeness, earnings management and disclosures of corporate governance information under SOX". The International Journal of Accounting, 44 (1), 1-32.

Christiani, I. and Nugrahanti, Y. W. (2014). "Pengaruh kualitas audit terhadap manajemen laba". Jurnal Akuntansi dan Keuangan, 16, 52-62.

CLSA. (2016). CG Watch 2016 Ecosystems matter: Asia's path to better home-grown governance. https://www.clsa.com/media-release-cg-watch-2016.

Cohen, J. R., Hoitash, U., Krishnamoorthy, G., \& Wright, A. M. (2013). "The effect of audit committee industry expertise on monitoring the financial reporting process". The Accounting Review, 89(1), 243-273.

D’Aveni, R. (1990). “Top managerial status and organizational bankruptcy”. Organization Science, 1(2), 121-142.

Dechow, P. M., \& Dichev, I. D. (2002). "The quality of accruals and earnings: The role of accrual estimation errors". The Accounting Review, 77(s-1), 35-59.

Dhaliwal, D., Naiker, V., and Navissi, F. (2010). "The association between accruals quality and the characteristics of accounting experts and mix of expertise on audit committees". Contemporary Accounting Research, 27, 787-827.

Erkens, D. H., and Bonner, S. E. (2013). "The role of firm status in appointments of financial experts to audit committees". The Accounting Review, 88, 107-136. 
Financial Reporting Council. (2010). The UK corporate governance code. London: Financial Reporting Council.

Gao, L., \& Kling, G. (2012). "The impact of corporate governance and external audit on compliance to mandatory disclosure requirements in China". Journal of International Accounting, Auditing and Taxation, 21(1), 17-31.

García, L. S., Barbadillo, E. R., \& Pérez, M. O. (2012). "Audit committee and internal audit and the quality of earnings: empirical evidence from Spanish companies". Journal of Management \& Governance, 16(2), 305-331.

Ghosh, A., Marra, A., \& Moon, D. (2010). "Corporate boards, audit committees, and earnings management: pre-and post-SOX evidence”. Journal of Business Finance \& Accounting, 37(9-10), 1145-1176.

Habbash, M., Sindezingue, C., \&Salama, A. (2013). "The effect of audit committee characteristics on earnings management: Evidence from the United Kingdom. International Journal of Disclosure and Governance, 10(1), 13-38.

Hadani, M., Goranova, M., \& Khan, R. (2011). "Institutional investors, shareholder activism, and earnings management". Journal of business research, 64(12), 13521360.

Kasznik, R. (1999). "On the association between voluntary disclosure and earnings management". Journal of Accounting Research, 37(1), 57-81.

Kothari, S. P., Leone, A. J., \& Wasley, C. E. (2005). "Performance matched discretionary accrual measures". Journal of Accounting and Economics, 39(1), 163-197.

Lin, J. W., Li, J. F., \& Yang, J. S. (2006). "The effect of audit committee performance on earnings quality". Managerial Auditing Journal, 21(9), 921-933.

Lo, A. W. Y., Wong, R. M. K., and Firth, M. (2010). "Can corporate governance deter management from manipulating earnings? Evidence from related-party sales transactions in China". Journal of Corporate Finance, 16(2), 225-235.

Meini, Z., \&Siregar, S. V. (2014). "The effect of accrual earnings management and real earnings management on earnings persistence and cost of equity". Journal of Economics, Business \& Accountancy Ventura, 17(2), 269-280.

Pollock, T., Chen, G., Jackson, E., andHambrick, D. (2010). “How much prestige is enough? Assessing the value of multiple type sof high-status affiliates for young firms". Journal of Business Venturing, 25, 6-23.

Rahman, R.A., \&Haneem Mohamed Ali, F. (2006). "Board, audit committee, culture and earnings management: Malaysian evidence". Managerial Auditing Journal, 21(7), 783-804.

Siagian, F. T., \&Tresnaningsih, E. (2011). "The impact of independent directors and independent audit committees on earnings quality reported by Indonesian firms". Asian Review of Accounting, 19(3), 192-207.

Siregar, S.V and Utama, S. (2006). "PengaruhStrukturKepemilikan, Ukuran Perusahaan danPraktik Corporate Governance TerhadapPengelolaanlaba (Earnings management)". Jurnal Riset Akuntansi Indonesia, 9 (3), 307-326.

Siregar, S.V and Utama, S. (2008). "Type of earnings management and the effect of ownership structure, firm size, and corporate-governance practices: Evidence from Indonesia". The International Journal of Accounting, 43(1), 1-27. 
Sharma, V. D., \&Kuang, C. (2014). "Voluntary Audit Committee Characteristics, Incentives, and Aggressive Earnings Management: Evidence from New Zealand". International Journal of Auditing, 18(1), 76-89.

Sun, J., Lan, G., \& Liu, G. (2014). "Independent audit committee characteristics and real earnings management". Managerial Auditing Journal, 29(2), 153-172.

Wallace, P. andZinkin. J. (2005). Corporate Governance. ISBN-10; 04070821124, Singapore: Willey.

Xie, B., Davidson III, W. N., \&DaDalt, P. J. (2003). "Earnings management and corporate governance: the role of the board and the audit committee". Journal of Corporate Finance, 9(3), 295-316.

Yusof, M.Md. (2010). "Does audit comittee constraint discretionary accruals in MESDAQ listed companies? International Journal of Business and Social Science, 1(3), 124136. 